\title{
Effects of Information Security and Innovations on Country's Image: Governance Aspect
}

\author{
Olha Petroye ${ }^{1}$, Oleksii Lyulyov ${ }^{2 *}$, Iryna Lytvynchuk ${ }^{3}$, Yurii Paida ${ }^{4}$, Vladimir Pakhomov ${ }^{2}$ \\ ${ }^{1}$ National Academy for Public Administration under the President of Ukraine, Kyiv 03141, Ukraine \\ ${ }^{2}$ Sumy State University, Sumy 40007, Ukraine \\ ${ }^{3}$ Zhytomyr National Agroecological University (ZNAEU), Zhytomyr 10001, Ukraine \\ ${ }^{4}$ Private Institution of Higher Education "Kamianets-Podilskyi Tax Institute”, Kamianets- Podilskyi 32301, Ukraine
}

Corresponding Author Email: alex_lyulev@econ.sumdu.edu.ua

https://doi.org/10.18280/ijsse.100404

Received: 20 March 2020

Accepted: 14 July 2020

\section{Keywords:}

state's image, information security, competitiveness, governance

\begin{abstract}
This paper summarizes the arguments and counterarguments within the scientific discussion on the issue of influence various information factors of economic, social, political, innovative and technological spheres on country's image. A special role in image shaping is played by non-material factors: information impacts, technologies and innovations development and governance efficiency. The aim of the study is to analyze the image of countries and to identify the impact of information security, innovations and effective governance on the image of countries. Methodological tools of the research methods were correlation and cluster analysis. CEE countries have been chosen as the object of research. The analysis has revealed a high correlation between the image of the states and its improvement and security indexes; Government Effectiveness Index; World Press Freedom Index; The Global Competitiveness Index.
\end{abstract}

\section{INTRODUCTION}

To obtain a positive image of the country, the formation of a favourable economic, financial and political environment and the avoidance of military conflicts are required. Information security, innovations and effective governance can be the significant factors in changing the state's image [13]. In particular, in terms of the governance effectiveness, these are publicity and authorities accountability, political and social stability, low level of corruption risks and inclination to corruption and negligence of bureaucracy, efficient legislative and executive branches $[4,5]$. With regard to innovations and information security, their negative status may cause a range of threats to the country's image: the emergence of disinformation and propaganda fields, negative impact on the image, conducting of information war in relation to the state, a number of cyber threats that may cause the real financial, economic, technological and image losses, while the lack of full access to technologies and information reduces the overall state's development level [6, 7]. Also, governance efficiency influences the efficiency of overcoming information threats and ensuring the information security of states.

The aim of the study is to analyze the image of countries and to examine the impact of innovation, information security and governance on their image. Central and Eastern European countries have been chosen as the object of the study.

\subsection{Materials and methods}

The research uses the following methods, namely: an economic analysis method in the analysis of theoretical and methodological bases for investigation of the problem; method of comparative analysis in the analysis of economic indicators; methods of generalization, systematization, synthesis, a study of phenomena and processes in their development and relationships, comparison, analogies, classification, grouping, etc. Central and Eastern European countries have been selected for the study (13 countries: Belarus, Bulgaria, the Czech Republic, Hungary, Lithuania, Latvia, Estonia, Moldova, Poland, Romania, Serbia, Slovakia, Ukraine). The informational base of the study was constituted by the reports for the period of 2010-2017: The Global Competitiveness Report (2015-2016), Fragile States Index, Global Cybersecurity Index (GCI), The Worldwide Governance Indicators (WGI), World Press Freedom Index.

Correlation analysis is used to determine the statistical interconnection among the indicators. The basic purpose of the analysis was to identify the impact of various factors, including information security, on the image of the countries. The main indicators for correlation analysis are the following: Innovation Index, Innovation Capacity, Fragile State Index, Security Apparatus Index, Government Effectiveness Index, World Press Freedom Index. The Global Competitiveness Index, Global Cybersecurity Index. The calculations were made using Statistica 7 software.

Pair correlation calculations were performed using the Pearson's $r$ pair correlation formula, due to the fact that this coefficient makes it possible to determine the linear relationship between two variables:

$$
r=\frac{\sum_{i=1}^{n}\left(x_{i}-y_{i}\right)\left(y_{i}-\bar{y}\right)}{\sqrt{\sum_{i=1}^{n}\left(x_{i}-\bar{x}\right)^{2}} * \sqrt{\sum_{i=1}^{n}\left(y_{i}-\bar{y}\right)^{2}}}
$$

where, $n$ - number of observations, sample; $x_{i}, y_{i}$ - individual values of variables; $\bar{x}=\frac{1}{n} \sum_{i=1}^{n} x_{i}, \bar{y}-$ the average value of the sample.

The value of pair correlation varies from -1 to +1 and 
indicates the presence of a direct or inverse relationship between variables. The closer the value is to -1 or +1 , the higher the degree of connection is between the variables. When assessing the presence of the level of connection between variables and confirming the hypothesis of the presence of connection, hypothesis $\mathrm{H} 1$ (no connection) is rejected at a certain level of significance, the probability of making error. To do this, use the p-value or the value of probability or asymptotic significance at the level of $1 \%(\mathrm{p}$ $<0.01000), 5 \%(\mathrm{p}<0.05000)$ or $10 \%(\mathrm{p}<0.1000)$ is used in order to do this. $5 \%$ error value is the most commonly used in accepting a statistical hypothesis when it is incorrect.

\subsection{Literature review}

\subsubsection{Country's image and image-shaping factors}

One of the key components of the image theory is defining of a certain set of events, phenomena or circumstances that can influence the formation of the international image of the country. Thus, a group of researchers [8-17] proposed a concept, according to which the image of the country depends on its organizational structure, distribution of functions among the authorities, internal structure and dynamics of state institutions, ways of formation of the official system of values and ideology by the authorities, social efficiency, composition of the administrative apparatus, role of small groups in politics, the political behaviour of the masses, etc.

Jefkins differentiates the following types of images: mirror image (according to the representatives of a certain institution, this is how the country looks in the mass consciousness), current image (the real image of the country, which can be based on an incomplete understanding or lack of information at the same time) and desired image (the image that the organization (country) would like to have) [18].

Holsti's in his work "The Belief System and National Images" demonstrated the connection between images and international conflicts. In particular, he has noted that policymakers act in compliance with their own understanding of the situation and the images of the countries - both the others and their homelands. These images, in turn, depend on the belief systems of policymakers, who may have a stronger or weaker link to reality [19].

Among the main elements of the image of the country, we should emphasize the image of the country's information policy: qualified personnel, reliability of information about the country, development of the mass media, level of censorship, transparency and accessibility of information, number of private mass media, integration into the world information space, etc. Economic factors, institutions are also determinants of the country's image and affect the level of investment in the country, and hence the level of innovation [20,21]. There is a significant link between security and the country's image [22]. A positive image of the country ensures the inflow of investment and the development of partnerships between countries, as well as the country's leadership in the international arena [23].

The analysis of the general principles of the country image formation provides the basis for their structuring by the following criteria.

Firstly, considering the purpose of the image creation, implementation and maintenance, the images are divided into positive ones, which evoke positive emotions (respect, honour, love, etc.) in relation to the image bearer, and negative ones, the purpose of which is to generate negative emotions (hostility, hate, contempt, etc.) in relation to the image bearer.

Secondly, according to the mechanisms of formation and distribution: spontaneous images, the formation of which in the mass consciousness was spontaneous. Their implementation takes a specified period of time. They are quite stable, as they rely not only on the associations of the new image with the current traditions, but they become traditional by themselves. The implementation can be carried out in the most acceptable time. However, they disappear from the public consciousness as quickly as they are implemented. Therefore, after the implementation of such images requires constant updating as long as it is necessary for the image bearers, or until they turn into some kinds of tradition.

\subsubsection{Information security and innovations and their influence on image shaping}

Information security is the state of protection of the information-related needs of individuals, society and the country regardless of internal and external threats. Regarding the national interests, information security means the state of individual, society and country information resources being protected, which ensures the implementation and progressive development of vital interests of the mentioned groups [24, 25] Information security is examined in three basic aspects: information protection, control over the national information space and sufficient information support for the governmental and non-governmental institutions, public and private organizations. In general, the information security level can influence the increase or decrease of the country's image.

Nowadays, innovative advances also influence the competitive positions of the country and its economic development. Innovations have a significant impact on economic transformations; changes in the economic structure of the country have a stimulating effect on the production development, science, researches, productivity and economy in general and increase of the scientific potential of the country [26-28]. This, in general, contributes to the country's image improvement.

The peculiarities and prerequisites for the image shaping and innovative advances of the Central and Eastern European countries are the following:

1. Separation of all Central and Eastern European countries without any exceptions from the socialist system (economic and/or political), which in many cases is associated with something progressive. The adoption of independence in Latvia in 1992 ensured its further economic growth. Since 1996, the GDP growth rate has been positive every year and has been characterized by a high level of economic growth. The country had been growing steadily until 2008 (average GDP growth rate was $7,427 \%$ annually) [29]. A similar situation was observed in Slovakia: GDP growth rates for the period 1993-2007 averaged 5, 075\% annually [29].

2 . Reducing the negative perceptions of the country and its population and strengthening of the positive perceptions. Some stereotypes have become so common that it seems to be quite difficult to change them, but perhaps the most effective way to do this is to gradually develop the diplomatic relations with these countries.

3. Perception of the country as a rightful member of the modern system which orients its policy towards the international community. In the case of CEE countries it means considering them as economically stable development partners which follow a democratic way. The main focuses of the foreign relations for the CEE countries are joining NATO 
and EU which are the most influential unions of the modern world.

4. The countries that conduct reorganization towards a market structure and implement structural reforms (this refers to Ukraine, Belarus and Romania) require political and economic assistance from more developed European countries. European countries branding is mainly aimed at the central and western parts of Europe.

5. Possibility for the country to show itself as a leader in a separate territory. CEE countries compete for the leadership in various spheres - economic, innovative, cultural, information and other. Such competition took place in the relations among Poland, Czech Republic and Hungary. Such competition generates the image-attractive regional leaders.

\section{RESULTS AND DISCUSSION}

According to Szondi, the countries of Central and Eastern Europe with transition economy with their similar geographical, economic, political and social systems and with the burden of the socialist past provide a vast field for analyzing and comparing the efforts of the image and the impact of innovations and information security on it [30].

As Melkonyan et al. claim, the political component of the European image is formed on the basis of politically significant events that have been taking place in the CEE countries. In the context of the political component of the European regional image, the central role is played by the organizations of the united Europe, such as European Union, the European Parliament, the OSCE, financial institutions, etc. Economic and industrial characteristics have a very significant role in the regional image shaping. This component of the image is preserved by means of economic reputation of the region [31].

The image of the CEE countries can be determined on the basis of the Fragile States Index and the Global Competitiveness Index. In turn, the Fragile States Index value is illustrative, which is defined within such limits: 18-20 - very sustainable; 20-30 - sustainable; 30-40 - very stable; 40-50 - more stable; 50-60 - stable; 60-70 - warning; 70-80 - elevated warning; 80-90 - high warning; 90-100 - alert; 100-110 - high alert; 110-114 - very high alert [32]. In 2017, 6 countries of Central and Eastern Europe were characterized by more stable level; in particular, these are countries with a higher level of GDP per capita and a high level of economic innovation (Poland, the Czech Republic, Lithuania, Latvia). Herewith, 4 countries (Ukraine, Belarus, Moldova, Serbia) were classified as "elevated warning", which means an increased level of danger, see Table 1.

Considering the groups of countries listed in the Fragile States Index, Ukraine is in the group "some worsening", which index increased by 2.6 during 2007-2017. At the same time, the dynamics of the image changes of the CEE countries is presented in such groups: "strong improvement" - Lithuania (-7.3), Poland (-6.8), Bulgaria (-6.6) and Romania (-10) "significant improvement" - Moldova (-13.7), Serbia (-11.1), Latvia (-10.3) "some improvement" - Estonia (-5.8) and Slovakia (-5) "marginal worsening" - Hungary (0.8) "marginal improvement" - the Czech Republic (2). Serbia's position among the countries that have most improved their Fragile States Index (FSI) over the past decade, has changed to negative one due to the country's role in the regional wars over the past 20 years. Starting from 2016, the country's economic, innovation and image indexes improved (in 2016, with the increase in domestic investment and the decrease in the unemployment rate from $17,7 \%$ in 2015 to $13 \%$ in 2016 ); however, this has not had a significant impact on the dynamics of the ranking yet.

The stability increase in Moldova is linked to its political and institutional reforms. Moldova's regulatory reforms, that started in 2014, have made it easier for local entrepreneurs to do business. For example, Moldova was ranked 92 among 178 countries in the World Bank's Doing Business Report in 2008. In 2018, it improved its position twice (ranked 47).

The index growth in Ukraine is also linked to the implementation of a number of structural reforms since 2015: deregulation of business, law enforcement system reform, innovative changes promotion, introduction of transparent procurement and public administration reforms.

Table 1. Fragile states index and the global competitiveness Index in CEE countries in 2017

\begin{tabular}{cccc}
\hline Country & Fragile States Index* & Classification & The Global Competitiveness Index \\
\hline Ukraine & 74 & elevated warning & 4.11 \\
Belarus & 72.4 & elevated warning & - \\
Lithuania & 41.7 & more stable & 4.58 \\
Latvia & 46.4 & more stable & 4.4 \\
Estonia & 44.7 & more stable & 4.85 \\
Moldova & 72 & elevated warning & 3.99 \\
Poland & 40.8 & more stable & 4.59 \\
Romania & 50.9 & stable & 4.28 \\
Hungary & 52 & stable & 4.33 \\
Slovakia & 44.3 & more stable & 4.33 \\
Bulgaria & 53.7 & stable & 4.46 \\
The Czech Republic & 40.1 & more stable & 4.77 \\
Serbia & 70 & elevated warning & 4.14 \\
\hline Source: the authors' research based on $[32,33]$ & &
\end{tabular}

The following parameters can be identified as the most influential for the CEE countries in the image structure of the Fragile States Index: the Factionalized Elites (Poland 4.2; Romania 5.4; Moldova 8.3; Serbia 8.0; Belarus 8.3; Slovakia 4.7; Hungary 5.3; the Czech Republic 5.0); the Group Grievance (Bulgaria 5.1; Romania 6.8; Moldova 7.3; Serbia 7.3; Latvia 8.0; Estonia 7.3; Slovakia 6.9; the Czech Republic
5.0), the Economic Decline Indicator (Lithuania 4.5; Bulgaria 5.7; Slovakia 4.6; Hungary 5.4; the Czech Republic 4.6), the Uneven Economic Development (Lithuania 4.5), the State Legitimacy Indicator (Romania 5.2; Belarus 8.7; Hungary 6.1), the External Intervention Indicator (Moldova 7.4; Belarus 7.3). For instance, in 2008-2018, the average annual GDP growth rate of Ukraine was $-1,002 \%$, while in Poland it was $3,456 \%$ 
annually [29]. For countries with stable economic growth (Bulgaria 2,031\%; Slovakia 2,549\%; Hungary 1,544; the Czech Republic 1,676\% annual GDP growth rate annually [29]) is characterized by a lower value of the Economic Decline Indicator in the system of Fragile States Index indicators. In CEE countries with economies in transition (Belarus, Ukraine, Serbia and Moldova) macroeconomic instability is observed, which is intensified during crises (2008-2009, 2014-2015) and manifested in economic downturn. For example, Ukraine's GDP growth in 2009 was $14,758 \%(2,304 \%$ in 2008$)$, in Moldova - $-6,000 \%(7,800 \%$ in $2008)$, and in Serbia - $-2.731 \%(5.656 \%$ in 2008) [29]. Corruption control is an additional factor of both political and macroeconomic stability, and accordingly affects the value of the Fragile States Index and the perception of the country in the world. These indicators are interrelated, as political stability and democracy determine the effectiveness of corruption control [34]. For instance, a weak level of corruption control is observed in Ukraine $\left(-0.87^{1}\right.$ according to the World Bank in 2018). The same situation is observed in Moldova (-0.73), Serbia (-0.37), Belarus (-0.19) [29].

For example, the greatest impact on Ukraine's image within the Fragile States Index was made by the following values: the External Intervention (8.6 in 2017), the Public Services (8.2 in 2017), The Security Apparatus (7.6 in 2017), The Factionalized Elites (8.0 in 2017), The Economic Decline (6.8 in 2017).

The country's image as well as innovative advances can be also characterized by the competitiveness index. Estonia, the Czech Republic and Poland are the most developed CEE countries in terms of competitiveness. The greatest impact on this index has been made by the institutions, infrastructure, higher education and training development, goods market efficiency and financial market development (in Estonia); by the institutions, infrastructure, health care and primary education systems development, goods market and labour market efficiency, technological readiness (in the Czech Republic); by the macroeconomic environment, higher education and training development, goods market efficiency and financial market development (in Poland).

In 2017, The Global Competitiveness Index was the lowest in Moldova (3.99), Ukraine (4.11) and Serbia (4.14), see Fig. 1b. The greatest impact on this index has been made by the institutions, labor market efficiency and financial market development (in Moldova); by the institutions, higher education and training development, goods market efficiency (in Ukraine); by the institutions, infrastructure, macroeconomic environment, higher education and training development (in Serbia). It is worth noting that the global competitiveness index in Ukraine, Serbia and Moldova in 2010-2017 has also improved. Indeed, the index has risen by $0.21 \mathrm{p}$. in Ukraine, by $0.30 \mathrm{p}$. in Serbia and by $0.13 \mathrm{p}$. in Moldova, see Figure 1.

While analyzing the innovation stimulation and innovative advances in the CEE countries in general, we come to the conclusion that we should highlight the Czech Republic, Estonia, Lithuania, Slovakia and Ukraine among the countries that demonstrate a positive innovation capacity. Moldova and Romania have some lower innovation capacity (see Figure 2b.).

However, the total innovation capacity of all CEE countries is lower than the innovation ability, as the index also includes the research work quality, educational institutions and enterprises cooperation, innovation expenditures and the production innovations implementation (see Figure 2a.). The most problematic issues are the implementation of innovations in the real economy, the use of scientific developments in production and the percentage of investment in enterprises innovations. All this reduces the total innovation index. It is obvious that the low innovation potential will not improve the image of the country.

Government Effectiveness Index is another indicator that somehow influences the image of the country. For their part, Romania, Ukraine, Belarus and Moldova lag behind the most considering the Government Effectiveness in 2017. This index has a negative value in these countries. On the contrary, the highest Government Effectiveness value is observed in the Czech Republic (1.02) and Estonia (1.12), see Figure 3.

It should be noted that over the 2010-2017 period the Government Effectiveness indexes in Romania, Ukraine, Belarus and Moldova have slightly improved. Indeed, during this period the index increased by $0.32 \mathrm{p}$. in Ukraine, by 0.76 p. in Belarus, by 0.10 p. in Romania and by 0.15 p. in Moldova, which means the government efficiency improvement. Analyzing the information security trends in the countries, we point that the Security Apparatus Index considers country's security threats, such as explosions, rebel movements, upheavals, terrorism and the information security threats. Regarding the security indicator, the lowest value is registered in Ukraine (7.6), and the highest ones are in Poland, Slovakia, the Czech Republic, Romania, Latvia, Lithuania and Estonia (see Figure 4a). If we analyze the cybersecurity levels of the countries, the situation here is somewhat different. For the Global Cybersecurity Index, Estonia (0.846), Latvia (0.688), Poland (0.622) and the Czech Republic (0.609) have the highest values. In their turn, Serbia (0.311), Slovakia (0.362) and Moldova (0.418) are considered to be the least secured countries in cyberspace, see Figure $4 \mathrm{~b}$.

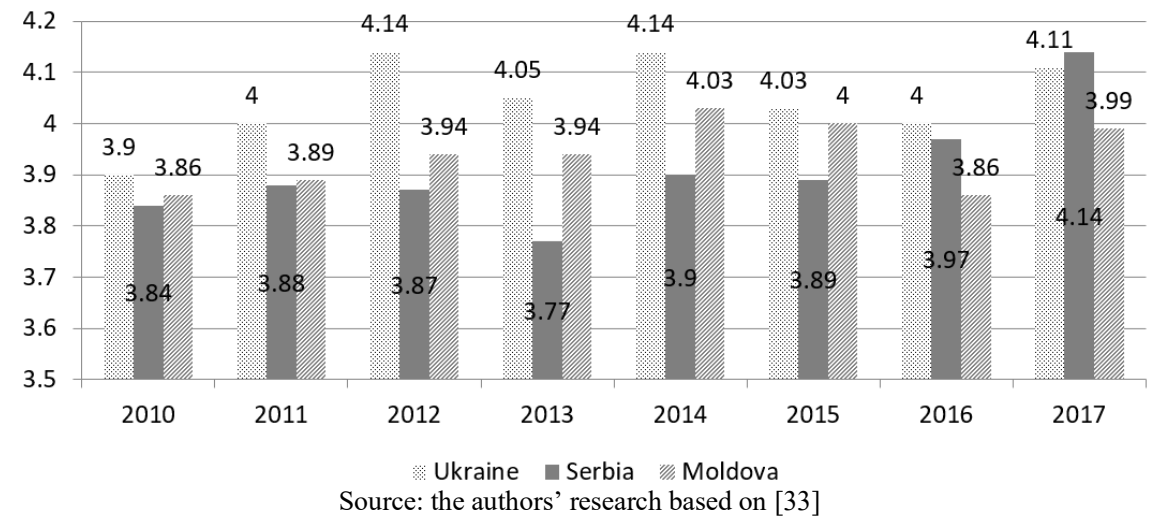

Figure 1. The global competitiveness index dynamics in Ukraine, Serbia and Moldova in 2017 


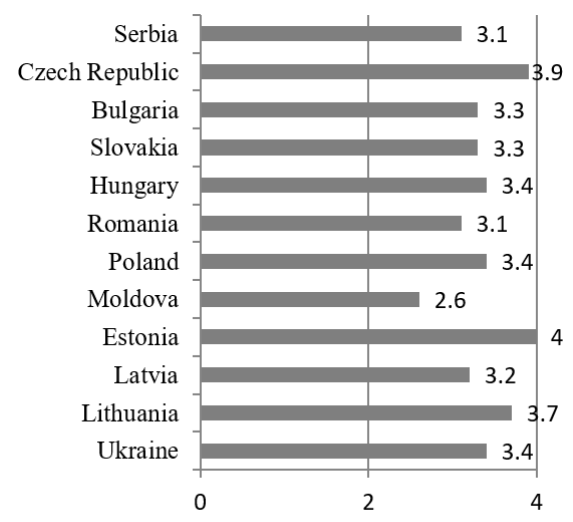

a) Innovation

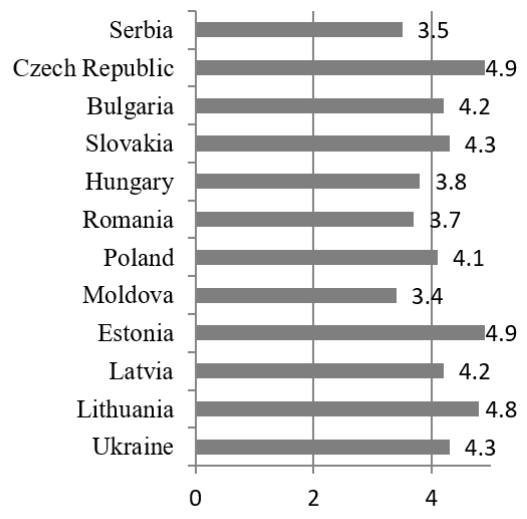

b) Capacity for innovation

Source: the authors' research based on [35]

Figure 2. World Innovation Index Structure

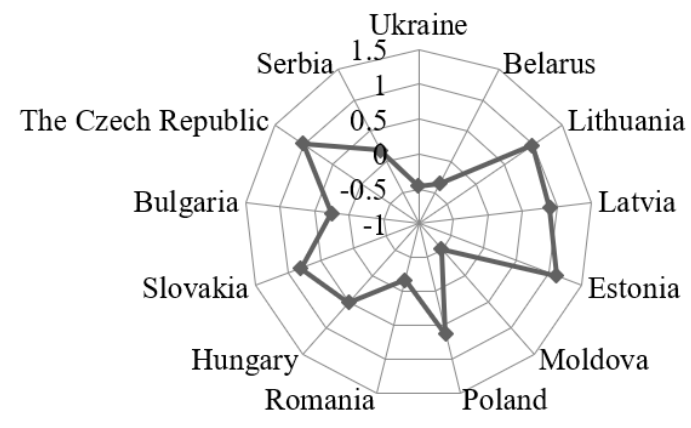

Source: the authors' research based on [36]

Figure 3. Government effectiveness index in the CEE countries in 2017

For the Global Cybersecurity Index, Estonia, Latvia and Poland have the highest levels of cybersecurity. Estonia focused better on its cybersecurity in 2007 and introduced an organizational structure that would react quickly to cyberattacks. The country also hosts the headquarters of the NATO Cooperative Cyber Defence Centre of Excellence. Estonia precedes the strategic development, launch and coordination of the country's brand in 2001-2002 in cooperation with Interbrand, an international branding agency. The Estonian brand model consists of several components (Estonian Branding Report, Enterprise Estonia, Tallinn).

The principled position was a clearly defined identity of Estonia as a European country. It included separation of the country from the Baltic group, because, as studies have shown,

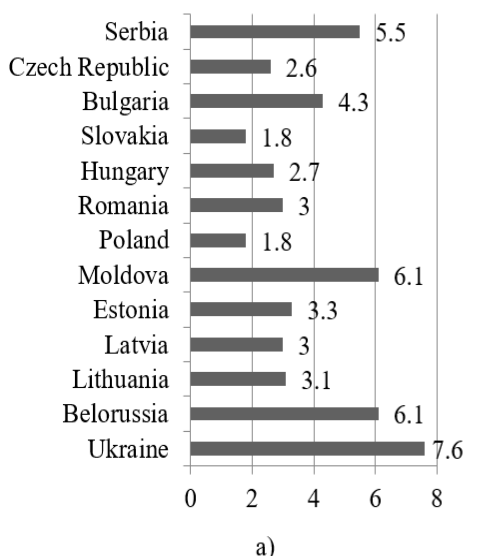

such positioning of the country can limit its potential and capabilities [30].

Latvia publishes a series of articles on free security solutions, such as antiviruses, firewalls, etc., twice a year on its national portal. The National CERT runs a campaign in which citizens can bring their computers and check them out, and also distributes a commercial antivirus, which is free for the period of one year.

For example, the Hungarian government was one of the first to create an organization to manage Hungary's image abroad. The purpose of the "Country Image Center" was "to develop a concept of a new country image and to construct this new image both inside and outside the country" [30].

According to the results of the paired correlation analysis (Table 1) a high degree of relation between the country image and its improvement and the Security Apparatus Index(r = 0.94 at $\mathrm{p}<05000)$, the Government Effectiveness Index $(\mathrm{r}=$ 0.88 at $\mathrm{p}<05000)$, the World Press Freedom Index $(\mathrm{r}=0.72$ at $\mathrm{p}<05000)$, the Global Competitiveness Index $(\mathrm{r}=0.41$ at $\mathrm{p}$ $<05000$ ) was established (Table 2).

At the same time, there is an interrelation between the country's security and public administration efficiency values (Figure 5): the Security Apparatus Index - the Government Effectiveness Index $(r=0.79$ at $p<05000)$; between free press indicator and competitiveness of countries: the World Press Freedom Index - the Global Competitiveness Index $(r=0.75$ at $\mathrm{p}<05000$ ); between press freedom and general security in the country: the World Press Freedom Index - the Security Apparatus Index $(r=0.65$ at $\mathrm{p}<05000)$.

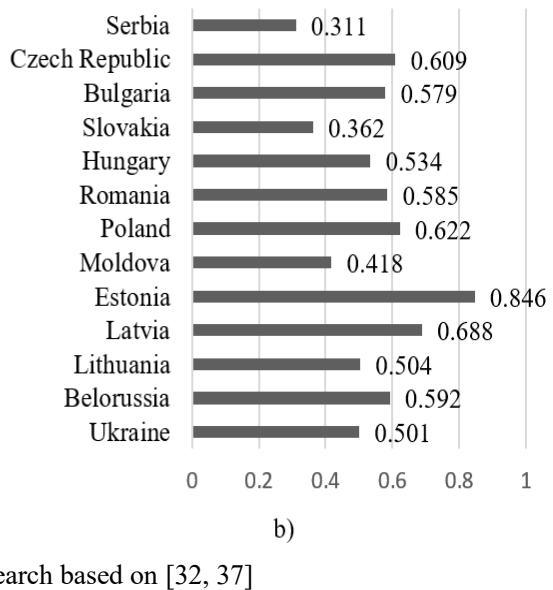

Figure 4. Security apparatus index and global cybersecurity index values in the CEE countries in 2017 
Table 2. Paired correlation analysis

\begin{tabular}{|c|c|c|c|c|}
\hline & $\begin{array}{c}\text { Fragile } \\
\text { States Index }\end{array}$ & $\begin{array}{c}\text { Security } \\
\text { Apparatus Index }\end{array}$ & $\begin{array}{c}\text { Government } \\
\text { Effectiveness }\end{array}$ & $\begin{array}{c}\text { World Press } \\
\text { Freedom Index }\end{array}$ \\
\hline Fragile States Index & 1.00 & 0.94 & -0.88 & 0.72 \\
\hline Security Apparatus Index & 0.94 & 1.00 & -0.79 & 0.65 \\
\hline Government Effectiveness & -0.88 & -0.79 & 1.00 & -0.75 \\
\hline World Press Freedom Index & 0.72 & 0.65 & -0.75 & 1.00 \\
\hline The Global Competitiveness Index & 0.41 & 0.35 & -0.36 & 0.75 \\
\hline Global Cybersecurity Index & -0.44 & -0.28 & 0.39 & -0.18 \\
\hline Innovations & 0.41 & 0.35 & -0.36 & 0.75 \\
\hline \multirow[t]{2}{*}{ Innovation Capacity } & 0.41 & 0.35 & -0.36 & 0.74 \\
\hline & $\begin{array}{c}\text { The Global } \\
\text { Competitiveness Index }\end{array}$ & $\begin{array}{c}\text { Global } \\
\text { Cybersecurity Index }\end{array}$ & Innovations & $\begin{array}{l}\text { Innovation } \\
\text { Capacity }\end{array}$ \\
\hline Fragile States Index & 0.41 & -0.44 & 0.41 & 0.41 \\
\hline Security Apparatus Index & 0.35 & -0.28 & 0.35 & 0.35 \\
\hline Government Effectiveness & -0.36 & 0.39 & -0.36 & -0.36 \\
\hline World Press Freedom Index & 0.75 & -0.18 & 0.75 & 0.74 \\
\hline The Global Competitiveness Index & 1.00 & 0.10 & 1.00 & 1.00 \\
\hline Global Cybersecurity Index & 0.10 & 1.00 & 0.10 & 0.10 \\
\hline Innovations & 1.00 & 0.10 & 1.00 & 1.00 \\
\hline Innovation Capacity & 1.00 & 0.10 & 1.00 & 1.00 \\
\hline
\end{tabular}

Source: the authors' own calculations based on $[32,37]$ and Formula (1)

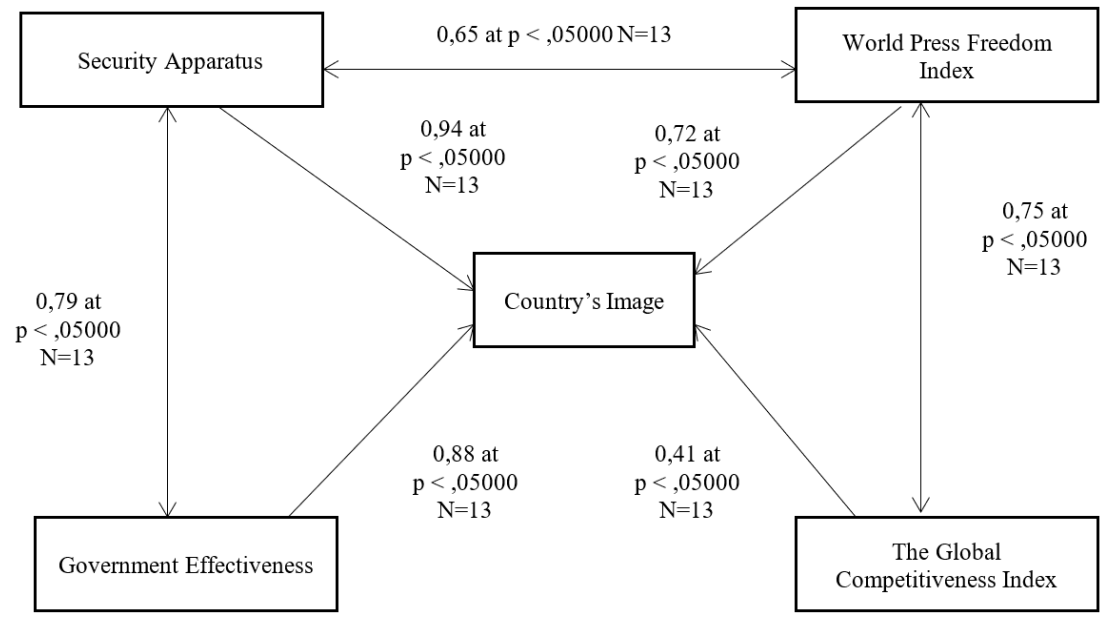

Figure 5. Impact of various factors on the CEE countries' images

If we analyze the separate correlation dependencies (see Table 2) of the Security Apparatus indexes in the CEE countries, we see that the total public administration efficiency level affects the country's security system. For example, in countries with low Government Effectiveness indexes, such as Ukraine (-0.46), Belarus (-0.35) and Moldova (-0.51) the security parameters are also low (Ukraine (7.6), Belarus (6.1), Moldova (6.1)). At the same time, in countries with significantly higher levels of public administration efficiency, such as Estonia (1.12), the Czech Republic (1.02), Slovakia (0.81), Poland (0.63), the security level is also considerably higher (the Czech Republic (2.6), Slovakia (1.8), Poland (1.8)).

Also, there are direct links between the public administration efficiency and the indexes of weak and strong countries. In countries with low parameters of Government Effectiveness (Ukraine, Belarus, Moldova) the following weakness parameters have been noticed: Ukraine (74), Belarus $(72,4)$, Moldova (72). Countries with high levels of public administration efficiency, such as Estonia, the Czech Republic, Slovakia and Poland, have the economic strength and positive image: Estonia (44.7), the Czech Republic (40.1), Slovakia (44.3), Poland (40, 8).

On the basis of the results of the study, we can identify several groups of the CEE countries being analyzed:
Group 1. Countries with more stable overall positive image, relatively high governance efficiency and high innovation capacity (the Czech Republic (40.1 - more stable; 1.02), Poland (40.8 - more stable; 0.63), Slovakia (44.3 - more stable, 0.81), Estonia (44.7 - more stable, 1.12), Lithuania (41.7 more stable, 0.98), Latvia (46.4 - more stable, 0.9). In such countries the information security level and the overall security level as well as the ability to innovate are high.

Group 2. Countries with a stable overall positive image, lower governance efficiency and lower innovation capacity: Romania (50.9 - stable, 0.17), Hungary (52.0 - more stable, $0.51)$, Bulgaria (53.7 - more stable, 0.26). The image of these countries is shaped and maintained by the overall image of EU member states, however, the governance efficiency level is not high, and information security and innovation capacity are also insufficient.

Group 3. Countries with an unstable (variable) image, low level of governance efficiency and high innovation capacity of Serbia (70 - elevated warning, 0.19). In Serbia, a low image level is combined with a low level of governance efficiency and a low level of information security and innovation.

Group 4. Countries with an unstable (variable) image, very low governance efficiency level and high innovation capacity: Moldova (72 - elevated warning, -0.51), Belarus (72.4 - 
elevated warning, -0.35) and Ukraine (74 - elevated warning, -0.46). These states are characterized by the negative experience of governance efficiency and a very low level of information security.

Today, there is a number of problematic issues in the image and innovation development of the CEE countries:

1. Lack of coordination among different strategies of the country's image shaping (the role of the country and its reputation, different directions of diplomacy): these elements do not resonate with each other. The country may have good indexes in one strategy but negative in the other.

2. Late start: this is true for most Eastern European countries. Image-shaping problems and the need for innovative solutions came to the fore only in the late 1990s. Only then did the governments begin to understand the role of the country's positive reputation and take steps to create it (Romania, Ukraine, Belarus, Moldova).

3. The country's progress is politicized and it depends on the situation in domestic politics. The image often suffers from disagreements in the views of different parties on the promotion of the country and the ways it should be implemented (it is typical for all groups of countries we have identified).

4. As a result, there are also problems with the constant promotion of a common image and information security strategies. Many countries have lost a lot in this regard in the moments when the new government came to power and devalued the previous government's work.

5. Problems in image shaping and information security are related to efficiency and management structure. There is a lack of a common strategy and coordination among the government authorities responsible for promoting the country; the most important thing is the coordination and subordination of all the involved subjects to a single strategy, however, a large number of institutions in this area can only create obstacles.

6. There are no clear differences among the images of different countries. Most of the main development strategies are similar to those of other countries and do not have clear differences. Countries define their advantages, but they are not specific and are not embedded in the international community's perception as the unique indicators of a certain country. It is often difficult to draw a clear line between certain countries in the same region, as they share many economic, cultural and social features.

7. Lack of economic, financial and human resources. This problem is relevant for the majority of countries, and it requires new and creative approaches which need fewer costs and are more effective, e.g., public relations.

8. Aiming at short-term rather than long-term results. This is especially evident in the countries of the Group 3 and 4. Governments of these countries often focus only on the current visible result of the image shaping but not on the long-term prospects.

\section{CONCLUSION}

According to the results of the conducted study, it has been found that the country's image in the world is influenced by information factors, in particular - information security, by the innovation potential and the ability to implement it. It has been found that country's image improvement depends also on the Security Apparatus, Government Effectiveness, World Press Freedom, The Global Competitiveness indexes improvement.
There is also a mutual influence among the country's security levels, including information security and public administration efficiency, free press and competitiveness of countries (World Press Freedom Index - The Global Competitiveness Index), between press freedom and general security in the country (World Press Freedom Index - Security apparatus Index). Weakness and strength of the country image is directly related to the level of information security, public administration efficiency and the opportunity to introduce innovations in the real economy. Among the problems of the image shaping of the CEE countries we distinguish problems in image shaping and information security related to the governance structure and efficiency, lack of financial and human resources, significant influence of political factors (the country's promotion is politicized and it depends on the situation in domestic politics), insufficient realization of the innovative potential of the countries; insufficient connection between scientific developments and their implementation in the real economy.

\section{ACKNOWLEDGMENT}

This research was funded by the grant from the Ministry of Education and Science of Ukraine No. 0117U003932.

\section{REFERENCES}

[1] Yuriivna, C.O., Sergiivna, K.V. (2015). Theoretical and applied aspects of the development of environmental investment in Ukraine. Marketing and Management of Innovations, (3): 226-234.

[2] Pająk, K., Kvilinskyi, O., Fasiecka, O., Miśkiewicz, R. (2017). Energy security in regional policy in Wielkopolska region of Poland. Ekonomia i Środowisko, 2(61): 122-138.

[3] Buriak, A.V., Lieonov, S.V., Vasylieva, T.A. (2015). Systemically important domestic banks: An indicatorbased measurement approach for the Ukrainian banking system. Prague Economic Paper, 24(6): 715-728. https://doi.org/10.18267/j.pep.531

[4] Vasylieva, T., Lyulyov, O., Bilan, Y., Streimikiene, D. (2019). Sustainable economic development and greenhouse gas emissions: The dynamic impact of renewable energy consumption, GDP, and corruption. Energies, $12(17)$ : 3289. http://doi.org/10.3390/en12173289

[5] Bilan, Y., Vasilyeva, T., Lyulyov, O., Pimonenko, T. (2019). EU vector of Ukraine development: Linking between macroeconomic stability and social progress. International Journal of Business and Society, 20(2): 433-450.

[6] Kwilinski, A. (2018). Mechanism of modernization of industrial sphere of industrial enterprise in accordance with requirements of the information economy. Marketing and Management of Innovations, 4: 116-128. http://doi.org/10.21272/mmi.2018.4-11

[7] Ibragimov, Z., Lyeonov, S., Pimonenko, T. (2019). Green investing for SDGS: EU experience for developing countries. Economic and Social Development: Book of Proceedings, pp. 867-876.

[8] Ibragimov, Z., Vasylieva, T., Lyulyov, O. (2019). The national economy competitiveness: Effect of 
macroeconomic stability, renewable energy on economic growth. Economic and Social Development: Book of Proceedings, pp. 877-886.

[9] Lunkova, V. (2016). Phenomenon of image in general and social psychology. Social Psychology, 3(17): 121132.

[10] Bilan, Y., Lyeonov, S., Lyulyov, O., Pimonenko, T. (2019). Brand management and macroeconomic stability of the country. [Zarządzanie marką i stabilność makroekonomiczna kraju] Polish Journal of Management Studies, 19(2): 61-74 https://doi.org/10.17512/pjms.2019.19.2.05

[11] Lyulyov, O., Chygryn, O., Pimonenko, T. (2018). National brand as a marketing determinant of macroeconomic stability. Marketing and Management of Innovations, 3:

$142-152$ http://doi.org/10.21272/mmi.2018.3-12

[12] Cotirlea, D.A. (2015). Country image vs. country brand: Differences and similarities. Ecoforum, 4: 165-171.

[13] Li, D.J., Ahn, J.S., Zhou, R.H., Wu, B. (2009). A study on the influence of country image on purchase intention of Chinese consumers based on Fishbein's model of reasoned action: Focused on USA, Germany, Japan and South Korea. Frontiers of Business Research in China, 3(4): 621-646. https://doi.org/10.1007/s11782-0090030-2

[14] Bannister J.P., Saunders, J.A. (1978). UK consumers' attitudes toward imports: The measurement of national stereotype image. European Journal of Marketing, 12(8): 562-570. ttps://doi.org/10.1108/EUM0000000004982

[15] Bilkey, W.J., Nes, E. (1982). Country-of-origin effects on product evaluations. Journal of International Business Studies, 13: 89-99. https://doi.org/10.1057/palgrave.jibs.8490539

[16] Brijs, K., Bloemer, J., Kasper, H. (2011). Country-Image discourse model: unraveling meaning, structure, and function of country images. Journal of Business Research, 64: 1259-1269. https://doi.org/10.1016/j.jbusres.2011.01.017

[17] Martin, I.M., Eroglu, S. (1993). Measuring a multidimensional construct: Country image. Journal of Business Research, 28(3): 191-210. https://doi.org/10.1016/0148-2963(93)90047-S

[18] Jefkins, F. (2008). Advertising. Practical Guide, 4.

[19] Holsti, O.R. (1962). The belief system and national images: A case study. Journal of Conflict Resolution, 6(3):

244-252. https://doi.org/10.1177/002200276200600306

[20] Andéhn, M., L'Espoir Decosta, P. (2016). The variable nature of country-to-brand association and its impact on the strength of the country-of-origin effect. International Marketing Review, 33(6): 851-866. https://doi.org/10.1108/imr-05-2015-0137

[21] Sun, Q., Paswan, A.K., Tieslau, M. (2016). Country resources, country image, and exports: Country branding and international marketing implications. Journal of Global Marketing, 29(4): 233-246. https://doi.org/10.1080/08911762.2016.1211782

[22] Mikhnevych, L., Marchenko, V., Hristov, P., Kuzior, A. (2020). Conceptual relationships between country image and economic security. Marketing and Management of Innovations,

(1):

$285-293$ https://doi.org/10.21272/mmi.2020.1-24

[23] Papadopoulos, N., Ibrahim, Y., De Nisco, A., Napolitano, M.R. (2018). The role of country branding in attracting foreign investment: Country characteristics and country image. MERCATI \& COMPETITIVITÀ, (2): 85108. https://doi.org/10.3280/mc2018-002005

[24] Kollár, C., VINÁRNÉ BELLÁSZ, Z. (2017). Terrorism and the information security of media content with special regard to ISIS, the Balkans and Russia. Socioeconomic Challenges, 1(1): 13-19.

[25] Ahmmed, M.M., Salim, Z.R. (2019). The impact of internet on the youth leadership. Business Ethics and Leadership, 3(3): 99-106. http://doi.org/10.21272/bel.3(3).99-106.2019.

[26] Kasztelnik, K. Gaines, V.W. (2019). Correlational Study: internal auditing and management control environment innovation within public sector in the united states. Financial Markets, Institutions and Risks, 3(4): 5-15. http://doi.org/10.21272/fmir.3(4).5-15.2019.

[27] Lyulyov, O.V., Pimonenko, T.V. (2017). Lotka-Volterra model as an instrument of the investment and innovative processes stability analysis. Marketing and Management of Innovations, (1): 159-169. http://doi.org/10.21272/mmi.2017.1-14

[28] Sineviciene, L., Shkarupa, O., Sysoyeva, L. (2018). Socio-economic and political channels for promoting innovation as a basis for increasing the economic security of the state: Comparison of Ukraine and the countries of the European Union. SocioEconomic Challenges, 2(2): 81-93. http://doi.org/10.21272/sec.2(2).81-93.2018

[29] The World Bank Development Indicator. https://data.worldbank.org/indicator/NY.GDP.PCAP.K D.ZG, accessed on May. 112020.

[30] Szondi, G. (2007). The role and challenges of country branding in transition countries: The Central and Eastern European experience. Place Branding and Public Diplomacy, 3(1): 8-20. https://doi.org/10.1057/palgrave.pb.6000044

[31] Melkonyan, N., Mramornova, O., Prots, T. (2012). Construction and representation of the "image" of Europe in the New Eastern Europe countries mass media (After the example of Armenian and Ukrainian print press). The Worldwide Governance Indicators: A Summary of Methodology, Data and Analytical Issues, pp. 41-50.

[32] Fragile States Index. https://reliefweb.int, accessed on May 12, 2020

[33] The Global Competitiveness Report 2010-2018. http://www3.weforum.org, accessed on May 10, 2020.

[34] Kaufmann, D., Kraay, A., Mastruzzi, M. (2010). The worldwide governance indicators: A summary of methodology. Data and Analytical Issues, World Bank Policy Research Working Paper, 5430. http://info.worldbank.org/governance/wgi/pdf/wgi.pdf, accessed on Apr 23, 2020.

[35] The Global Innovation Index. www.wipo.int, accessed on May 10, 2020.

[36] The Worldwide Governance Indicators (WGI) project. https://info.worldbank.org/governance/wgi/\#home, accessed on May 11, 2020.

[37] Global Cybersecurity Index (GCI). https://www.itu.int, accessed on May 12, 2020. 